\begin{abstract}
371.3::811.163.41'242
811.163.41'373.611

https://doi.org/10.18485/msc.2017.46.3.ch2

\author{
Драгана Д. ВЕљКОВИЋ СТАНКОВИЋ ${ }^{*}$ \\ Филолошки факултет \\ Универзитета у Београду
}

\section{О РАЗВОЈУ ЛЕКСИКОНА У НАСТАВИ ТВОРБЕ РЕЧИ}

У раду се бавимо унапређењем корелацијско-интеграцијског приступа у настави српског језика као матерњег. Будући да смањене изражајне способности ученика корелирају са све неразвијенијом навиком читања и применом репродуктивно-експликативних поступака у настави језика, побољшање квалитета наставе и знања видимо у интензивнијем повезивању и прожимању унутарпредметних области, а у фокусу разматрања су настава творбе речи и културе изражавања. Циљ интеграцијског и комуникативног приступа јесте оспособљеност ученика за активну примену знања из творбе речи уз проширивање вокабулара, а основни преуслови реализације ових наставних задатака јесу (а) интензивније повезивање наставе творбе речи са семантиком; (б) темељна обрада и боља диференцијација основних појмова и термина из ове области (уп. експланативна функција појмовних метафора у настави); (в) коришћење систематизације и писмених провера знања зарад богаћења активног речника (уп. утицај теста на наставу, валидност одговора).
\end{abstract}

Кључне речи: творба речи, унутарпредметна корелација, активни речник, појмовне метафоре у настави, тестови, валидност одговора

1. О значају повезивања наставних садржаја. Проблем сужавања вокабулара није нов нити лак за решавање у наставној пракси. На први поглед он проистиче из све нижих програмских захтева и мањих очекивања наставника, али дубље, истинске разлоге ваљало би потражити у снижавању критеријума у друштву у коме се немуштост и језичка некултура, па и други облици удаљавања од вредности достојних неговања све чешће олако прихватају. Сужавајући фокус на наставу матерњег језика, уочавамо бројне узороковаче осиромашења речника: од нечитања и повлађивања удаљавању од лепе књижевности редукцијом обавезне лектире до наглашене афирмације визуелних медија и маргинализације доброг, лепог и јасног изражавања, од недостатка квалитетне комуникације у настави до немогућности разумевања

\footnotetext{
*draganavs@yahoo.com
} 
књижевних дела. И поред несумњивог труда који се улаже у осмишљање наставних приступа и савладавање градива - због релативно ниског нивоа координације наставних садржаја - напредак није увек сасвим задовољавајући. Зато ћемо пажњу усмерити пре свега на недостатке повезивања различитих области наставе српског језика, јер је запажено да се, на пример, знања о творби речи све чешће своде само на упознавање (и препознавање) творбених начина, дакле, на „механику” грађења речи; веома ретко се инсистира на значењима твореница, још ређе се употреба тих речи показује у разговорном језику и спаја с наставом књижевности, а велики описни речници се - упркос бројним препорукама (научним и стручним радовима који се баве овом тематиком) - у наставу уводе тек изузетно, најчешће само на угледним часовима, а понегде и на часовима додатне наставе и лингвистичке секције. Поред тога, тестови, као писмене провере знања које могу постати извор добрих корективних, али и креативних методичких модела, веома ретко бивају коришћени са циљем побољшања културе изражавања. Више пажње поклања се меморисању чињеница, а премало показивању њихових саодноса и онога што се захваљујући њима може остварити. Тако се фаворизују парцијална знања и формира квазиутилитаран став према знању уопште, па и према језичком знању; све чешће се учи за оцене, или „за тестове”, а све ређе се води рачуна о томе колико ће они, ваљано интегрисани у наставу, допринети остваривању најважнијих задатака учења матерњег језика.

Од ђака се често може чути да часове матерњег језика доживљавају као граматичке дрилове, на читање гледају као на излишно губљење времена, а ниво аспирације је врло мали. Ученици су углавном задовољни својим изражајним способностима, чак и када оне нису завидне, док су висока постигнућа најчешће резултат индивидуалних напора и често су, нажалост, кратког даха, особито када не наиђу на довољну подршку школе и друштва.

На часовима матерњег језика и књижевности описи и карактеризације јунака уметничких дела, али и казивања везана за свакодневне догађаје и лична искуства постају толико штури и уопштени да каткад губе информативност. На пример, поступак неке особе или књижевног лика одређује се као „лош”, „негативан”, без напора за прецизнијом квалификацијом (уп. себичан, ускогруд, издајнички, пакосан, подао и сл.); категоризација је груба, сведена на предзнак, а садржај минималан, што значи да је мало тога запажено и схваћено, ако и јесте, подесна реч тешко се налази, па анализа остаје површна, а допринос когнитивном и језичком развоју минималан.

Сматрамо да се развој језичке културе може боље, и то системски умрежити у наставне садржаје из области језика, чак и у оне за које влада уверење да су намењени искључиво мерењу и процени знања - у тестове. Укратко, залажемо се за функционалнији и с другим областима језика оптимално интегрисан приступ настави творбе речи и продуктивнији начин коришћења тестова у настави. Тако би се истовремено изграђивао вокабулар и ширила знања из лексикологије и семантике, а истовремено повећали изражајни потенцијали. 
Иако ће методичке препоруке бити базиране на анализи постигнућа студената прве године Филолошког факултета у Београду на тестовима из области творбе речи (у оквиру испитне провере знања из предмета Српски језик 2), тежина и типови решаваних задатака нису у толикој мери удаљени од нивоа примереног средњој школи да се резултати не могу посматрати, а потом и применити са циљем унапређивања наставе, као и зарад побољшања функционалне примене тестова у настави творбе речи. Посебно треба нагласити важност испитивања валидности одговора, које се у академским условима може спроводити само у оквиру вежби, али је овај поступак и те како применљив у школској настави. Имајући у виду корист коју за успех у стицању знања и побољшању наставних приступа (уп. утицај теста на наставу, Вељковић Станковић 2007б: 204-208) имају анализа тестова и провера валидности одговора, посматрање резултата тестова настојали смо оптимално прилагодити околностима и циљевима средњошколске наставе, како би запажања, која из датих анализа произилазе, била што применљивија у наставној пракси.

Методичка литература не оскудева у веома компетентним и корисним методичким препорукама посвећеним настави творбе речи и апликацијама које су добар водич у реализацији обраде и систематизацији знања (Петровачки и Штасни 2008: 132 143), а овој теми посвећена је и научна монографија (Штасни 2009), у којој су презентовани и ваљано разрешени многи проблеми који се тичу научних и наставних приступа. На темељу ових, али и знатно старијих, но за наставу једнако важних методичких путоказа Александра Белића, представићемо потенцијале коришћења валидности одговора на примерима задатака усмерених на проверу знања из творбе речи и указати на добробит успостављања унутарпредметних корелација.

2. Актуелност Белићевих препорука у вези са наставом творбе речи. У предговору Граматике српскохрватског језика за І разред средюих школа, А. Белић и А. Жежељ, аутори овог уџбеника, истичу да су посебно водили рачуна о функционалности, и то не само зарад боље и лакше перцепције садржаја, већ и с намером да ученицима омиле учење матерњег језика и да подстакну њихову радозналост, због чега су текстове, објашњења и начин излагања прилагодили узрасту: „Настојали смо не само да будемо јасни и поступни, него и да унесемо живости и непосредности у општење с ученицима. Ако граматика није увек лака и забавна, то није разлог да буде суха и досадна".

Након напомена у вези са важношћу квалитета обраде, наставних материјала и значаја самосталног рада, коме су намењене бројне вежбе, аутори закључују: „Уопште, руководили смо се основним начелом да ономе ко у језик и вештину изражавања мисли не уђе самостално, својом главом и разумевањем, томе језик остаје вечита загонетка" (Белић и Жежељ 1940, у: Белић 2000). Од укупно 28 лекција, од којих се састоји ова граматика, лекција о грађењу речи укључена је међу почетне кораке у учењу матерњег језика, и увршћена, као пета по реду (одмах после лекција Наш језик, Наше писмо (или азбука), Речи, Гласови), у овај уџбеник, по чему јасно препознајемо Бе- 
лићеву реализацију поступности и став према значају доброг овладавања знањима из ове области.

Белић је имао веома добро развијено осећање за усаглашавање методичких поступака са циљевима наставе. У свом чланку „О нашој средњошколској граматици" (1934; у Белић 2000: 400-408), аутор је - нагласивши да је задатак наставе матерњег језика и уџбеника да „доведе до пуне свесности оно што он [ученик] употребљава" - указао на бројне недостатке наставе језика који су се, између осталог, огледали и у запостављању синтаксе и науке о грађењу речи (Белић 2000: 404-405). За такво стање није кривио своје претходнике, чији је допринос био неспоран (посебно не Новаковића, који се у састављању своје граматике водио за Даничићевим Основама, нажалост, неупотребљивим у школама), већ догогодишњу инерцију потоњих језикословаца и писаца уџбеника који су некритички преузимали садржаје из старијих граматика, не усклађујући их научно, методолошки, па ни методички с потребама наставе. Неповољне околности погоршала је стагнација у изучавању творбе речи, што се и те како одразило на низак квалитет ученичких знања. Поводом избацивања овог дела граматике из наставних програма, Белић је енергично негодовао: „Та нико ваљда неће спорити нашем језику да је по грађењу изведених речи један од најбогатијих језика! Изведене речи скривају у себи необично богатство нашег језика и неисцрпан су извор за грађење нових речи. Колико је баш тај део граматике био потребан нашем друштву које је - ослободивши се робовања различитим народима - желео да се ослободи и трагова тога ропства, од многобројних страних речи које су од њега остале! И колико је - због недовољне спреме и разумевања овог посла - сковано рђавих кованица које су доцније служиле као углед за нове кованице и шириле кварење нашег језика!" (исто, 404). Наш знаменити филолог указује и на то колико је важно деци приближити „механизам стварања речи” како би могла познати „да ли је која реч добро начињена или није и како би је ваљало начинити кад устреба" (исто, 405).

Колико је брига за добро усвајање творбених образаца примерених српском језику важна најбоље ће показати следећи примери, у којима је највећи део оказионализама неприхватљив, и то не само зато што нису грађени према продуктивним обрасцима или што су фонетски незграпни (уп. *априродан, *негојећи, *потрошаштво и сл.), већ и стога што - управо због непознавања семантичког учинка афикса - каткад имају обрнуто значење од намераваног (нпр. *нераскићен = онај који је /joш/ окићен; уп. РМС раскитити = скинути, разметнути окићено), или пак никаквог одређеног смисла немају (*несеоски $\neq$ (при)градски / варошки ?). Међу њима се лако нађу и рђаво „сковане” речи, сасвим непотребне српском лексикону (*утечнити, *априродно), које пре откривају сиромаштво речника, но лудистички порив за лексичким иновирањем. Потенцијалном речју могла би се сматрати само им. заливач (= онај који залива /цвеће/), сачињена према знаном и веома продуктивном творбеном моделу (уп. поливач, приређивач, добављач и сл.): 
- Људска врста се у ово доба дели на оне Срећнике који су на море отишли и Залива-

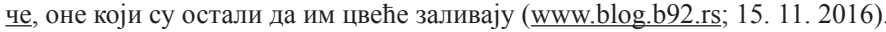

- Нема празника коме се не пребацује отрцаност, потрошаштво... (www.blog.b92.rs).

- ...бака се свим својим снагама трудила да остане у оази несеоског начина живота... (www.blog.b92.rs).

- Цакли [ce] јелка нераскићена... (www.blog.b92.rs).

- Онда бих се нашла са другарицама и ишле бисмо код ње на ситне колаче и негојећи сланиш (www.blog.b92.rs).

- Припрема: Утечните вазелин помоћу водене паре (webtribune.rs; 10. 12. 2016).

- ...било је нешто априродно у тој боји косе (www.forum.b92.net; 3. 2. 2017).

Није реткост да се у новинарском стилу, као и у свакодневним разговорима јаве индивидуализми, обично из потребе да се штогод новим именом издвоји и/или да се духовитим, занимљивим творбеним актом скрене пажња саговорника (уп. огромантан = огроман + импозантан; рогобатница = рогобатна, неправилна реч и сл.), али се у настави треба трудити да ученици изграде добро језичко осећање и да препознају творбене незграпности и семантички неадекватне, невешто саздане речи и изразе, те да их разликују од потенцијалних речи (Драгићевић 2009).

И у својим раније штампаним граматикама Белић апострофира значај творбе речи за добро познавање и владање матерњим језиком. Тако, у предговору Граматике српскохрватског језика за други разред средњих и стручних школа (1932), он образлаже због чега је одељак посвећен грађењу речи ставио одмах после дела о гласовима, а испред поглавља о падежима и промени именских речи, а такође указује на окосницу усвајања знања из творбе речи: „...сматрао [сам] за потребно да одељак о грађењу речи и значењима речи у вези са њиховим грађењем ставим испред одељка о значењима падежа. Ја се надам да ће се г. г. наставници сложити са мном да овај одељак граматике, ако се у њега унесе она живост коју може да даิ жива реч, може побудити и нарочито интересовање код ученика. Питања ове врсте, која ученик може лако пратити на своме језику, привлаче увек ученичку пажњу. Али се и ту треба задржавати само на ономе што је од правог значаја; а то су значења речи у вези са грађењем од различних врста речи" (Белић 1932: III-IV).

Богаћење речника доприноси повезивању идеја и развоју мишљења. Свестан тога, Белић инсистира на функционалности знања које треба градити у складу са функционалношћу језика: да би се упознала промена, мора се поседовати развијен речник из кога и долази „материјал” за промену, јер граматичка знања о облицима не вреде много ако је вокабулар, као базичан језички резервоар, празан. За његово ширење, као и за повезивање творбе речи са семантиком, за које се Белић посебно залаже, неопходно је заинтересовати ученике занимљивим приступима (отуда спомиње „живост коју може да даิ жива реч”), које један уџбеник никада не може у оптималној мери оцртати, нити понудити. Инвенција наставника у овом осетљивом делу обраде је неопходна. Белић упућује и на коришћење језичког осећања ученика. За активирање и праћење овог осећања потребно је и стрпљења и умења, обостраног труда - ученичког и наставниковог. Но, настава грађења речи често 
се своди на механичко запажање подударности гласовног састава речи, да би се потом извео закључак о учешћу творбених елемената. Такав поступак не погодује ни развоју научних појмова, нити развоју мишљења, који су у тесној, каузалној вези са проширивањем вокабулара. Богаћење речника такође погодује и проширивању ванлингвистичких знања и дубљем упознавању властите културе. ${ }^{1}$

Белић је такође указао и на важност контекстуализације у настави, тј. коришћења доброг и природног контекста: „У предавању језика мора се полазити од реченице, зато што ми реченицама говоримо и зато што све добива у језику у реченици своје крајње формирање: и облик, и значење, и веза речи и израза у њој. [...] Реченица мора бити, у предавању матерњег језика, наш стални пратилац за значење и употребу сваког облика о коме се говори” (Белић 2000: 403).

Укратко, ако би се Белићеве поруке, о којима је овде било речи, максимално сажеле и саобразиле језику методике наставе, могле би се свести на следећу „формулу”: компетентност (наставника и уџбеника), уз смислено учење, контекстуализацију наставних садржаја, повезивање области језика и обиље вежби води овладавању правилним књижевним језиком и развијеној оспособљености за ваљано изражавање. Пут је, дакле, био јасно и добро трасиран, но, прескачући велики временски одсек који нас дели од периода када је А. Белић осмишљао и писао своје уџбенике, те враћајући се у данашњу ситуацију, запажамо немали несклад: у међувремену је, без обзира на то што у дериватологији још није достигнута жељена усаглашеност на теоријском плану, наука о творби речи знатно узнапредовала, теорија уџбеника је такође у успону, па је - у складу с тим - и квалитет граматика битно побољшан, но, знањем ученика о грађењу речи не можемо се много похвалити. Још мање разлога за задовољство пружа развијеност ђачког вокабулара, који треба сматрати незаобилазном основом за усвајање знања о творби, јер без познавања речничког блага - као изворишта творбеног „материјала” - не може бити ни знања о грађењу нових речи. Очито је да су две, међусобно супротне тенденције - гомилање (добрим делом непотребних) чињеница из различитих предмета и напор да се обим лектире (школске и домаће) смањи довеле до конфузне, па отуда непродуктивне селекције. Под притиском заговорника преоптерећености „обимним” књижевним делима, поступно се посустајало али, надамо се, не и потпуно одустало од инсистирања на развоју читалачких навика. Читање и тумачење књижевних дела - као један од најважнијих начина којим се подстичу менталне функције, обогаћује унутрашњи свет и обликује индивидуални језички израз - најпре је почело да губи свој повлашћени статус у колективној свести, а потом је, са поплавом „лаке” литературе, избледело достојанство интелектуалног изазова класика домаће и светске књижевности. Ови процеси су се у настави очитовали у

\footnotetext{
${ }^{1}$ На пример, увођење мање познатих речи којима се именују стари занати, занатлије, називи одевних предмета, тканина од којих су направљени, справа помоћу којих су израђивани такви материјали, украса и делова народне и градске ношње и сл. требало би да буде уткано у занимљиво приповедање о одређеном времену, начину живота, навикама, обичајима и др.
} 
миноризовању значаја лепе књижевности за општи развој ученика, а значајно је истаћи да су текли паралелно с маргинализовањем учења матерњег језика и запостављањем поштовања језичке норме, али и других културних вредности. Премда се можемо надати да ће овакав тренд с временом ослабити и уступити место образовној политици изграђивања интелектуално и духовно јаких, на најбољим примерима наше традиције и савремене науке васпитаних генерација, последице су увелико видљиве, не само у усмерености младих на читање добрим делом испразних садржаја, већ и у сиромаштву идиолеката ученикаิ.

Управо зато, уместо ламента над блеђењем „старинске” навике разговора с књигом и о књизи, ваља се усредсредити на могућности повезивања наставних садржаја грађења речи са културом изражавања. Један од главних повода за то јесу запажања у вези са међуусловљеношћу развијености вокабулара и знања о творби речи. Следствено томе, полазимо од следећег проблема: ако, аналогно попустљивом ставу према смањивању наставних садржаја из књижевности, (последично) прихватимо и чињеницу о сиромаштву вокабулара на такав начин да наставу језика, посебно творбе речи, једнако као и проверу знања саображавамо невеликом и, у крајњој линији, комуникативно неефикасном речнику, чинићемо једнак или сличан грех оном на који је Белић својевремено упозорио, а тицао се могућности преношења захтевнијих наставних садржаја (из синтаксе и творбе речи) из нижих и више разреде: „...због тога што је нешто сложеније и теже - сводити га на просто и нетачно и тиме хранити децу, то је грех" (Белић 2000: 407).

3. Појмовне метафоре у наставном дијалогу. Употреба метафора у основном и допунском тексту савремених уџбеника није реткост, а подсетићемо се да је и Белић у својим граматикама, а у име рационалног олакшања учења, прибегавао (и то веома успешно) метафоричком изражавању. Тако је, на пример, корен речи објашњавао као прародитеља „од кога води порекло цела једна многобројна породица речи. Само с том разликом што у људској породици преци умиру и нестаје их, док се у језичкој чувају у свакој речи” (Белић 2000: 293). Уз то, различита вежбања понуђена у тим уџбеницима показују да су ученици били оспособљавани да творбене елементе и састав твореница препознају у одломцима књижевних дела (у читанкама). Данас се, међутим, знања из творбе по правилу стичу на примерима у нултом контексту, а исто се тако и проверавају, па је сасвим извесно да би у савременим условима овакав захтев био оцењен као преамбициозан и претежак, и то без обзира на узраст ученика; основни повод негодовању био би тај да се у књижевним делима (старијих али и савремених писаца) употребљавају речи које су њима непознате и отуда непогодне за творбену анализу. ${ }^{2}$

\footnotetext{
${ }^{2}$ Ово, међутим, није тачно, не само зато што је повезивање наставе језика с наставом књижевности неизоставно (особито приликом анализе језика одређеног књижевног остварења), већ и зато што се нпр. поетизми и њихова творбена мотивација не могу сагледавати и анализирати изван поетског контекста; један од најупечатљивијих примера јесу стихови Лазе Костића: „Из црног мрака дивна ми свану, / к’о песма славља у зорин свит... / Она ме гледну. У душу свесну / никад још такав не сину глед... / ... сву своју душу, све своје жуде, - сву вечност за те, дивни тренуте! Santa Maria della Salute".
} 
Претходни наводи показују да је Белић јасно препознао моћ метафоре у наставном дискурсу и да ју је с мером, али изванредно умешно употребљавао на корист ученика. Чини се да би се и многи недостаци у савременим приступима творби могли отклонити, или бар умногоме ублажити сличним поступањем, а ту, пре свега, мислимо на (не)разликовање творбене основе 3 од корена речи.

Рекли бисмо да до наизглед неочекиване интерференције ових термина (и њихових појмовних садржаја) долази понајпре због блискости значења именица корен и основа у колоквијалном и књижевном језику, због које се концептуално замагљује важна разлика међу њима, а то се потом рефлектује и на поимање и идентификацију ових творбених јединица. Зато је веома важно да у настави ови термини буду правилно схваћени и на одговарајући начин диференцирани.

РСАНУ: основа 1. а. део зида грађевине, зграде испод повриине тла који служи као ослонаи зидовима, темељ. 2. а. оно на чему се нешто темељи, заснива, темељ, база; полазна тачка, исходиште. 6. лингв. део речи који се у промени (деклинацији, конјугацији или творби) не мења, односно који преостане када се одбаце деклинацијски, конјугачијски или творбени наставци. 10. а. биол. доњи део, почетак неких биљних или животињских органа који служи као веза са осталим деловима организма, корен, база: језика, листа.

корен 1. орган биљке који обично расте под земьом и којим се биљка учвршћује за земљу и узима из ње воду и храньиве састојке. 4. фиг. а. темељ, основа, оно што је главно, најважније, најзначајније. 5. лингв. првобитни, основни, семантички нерашчлањиви део речи који је обично заједнички за вище речи.

Велик број грешака које се јављају на свим школским нивоима показује да базични проблем представља непоуздано поимање творбене основе, док се корен речи много лакше разазнаје и у твореницама препознаје. Метафоризација овог лингвистичког термина подстакнута је не само фигуративним значењем им. корен (4), већ и доста уобичајеном применом принципа очигледности преко илустрација у школским граматикама, у којима је корен биљке приказан као корен речи (исп. Николић ${ }^{42006: 681), ~ д о к ~ с у ~ н а ~(н а д з е м н и м) ~}$ изданцима или листовима исписани суфикси којима се добијају првостепени деривати. Такве илустрације су добре у почетној фази учења творбе речи, и биле су применљиве код млађих ученика, када је грађење речи - према ранијем наставном програму - било обрађивано у петом разреду основне школе. Поред корена, у овој области језика јављају се и многи други у битти метафорични термини који се лако разумеју преко појмовних метафора: породица речи, творбена основа, мотивација, мотивна реч, мотивисана реч, деривационо гнездо, слагање, сраслица. Наравно, све почиње од назива ове језичке области - творбе / грађења речи, и његове полисемантичности (назив лингвистичке дисциплине и термин којим се означава сам процес добијања нових речи, исп. Ћорић 2008: 14), а потом и „продуката” овог процеса - творенииа (уп. творбена реч, Ћорић 2008: 11).

\footnotetext{
${ }^{3} \mathrm{O}$ употреби терминаิ творбена основа, коренска основа, лексичка основа и основна реч исп. Милановић 2009: 130-131).
} 
У настави метафоре представљају средство развоја нових концепата, зато је важно да се користе оне метафоре које ће - у складу с приципом научности - откривати, па самим тим и утемељити она дистинктивна својства лингвистичког појма која омогућавају ваљано разумевање језичких појава, како би, на таквим темељима, знања која се касније стичу била поуздана и операбилна. Наставне метафоре стога имају знатан утицај на продуктивност наставе и учења; оне могу бити ефикасне, тј. продуктивне, али и лимитативне. Ове потоње - управо због усмерености на небитну карактеристику језичке појаве, или због могућности настанка негативних импликација - често постају ометач даљих когнитивних процеса. Стога наставне метафоре треба посматрати с обзиром на њихов откривалачки потенција, тј. способност да побуђују концептуалне иновације, да особености језичких појава учине „видљивијима”, и с обзиром на већ постојеће искуство - јаснијима. Употреба операбилних појмовних метафора у настави може се сматрати моћним идентификационим и објашњавачким поступком. Зато овај когнитивни механизам треба опрезно примењивати, имајући у виду потенцијалне негативне исходе. Поред неразликовања творбене основе и корена речи, често се наилази на грешке као последице неразликовања граматичке и творбене основе. Стога разликовању ових двеју основа ваља посветити посебну пажњу тако што ће у провере знања, поред твореница које имају исту творбену основу, бити укључени и различити облици основинских речи. Такве поступке препоручују врсни методичари, и то не само у обради, већ и у систематизацији и утврђивању знања (исп. Штасни 2008: 219).

Појмовна метафора уводи се у наставни дијалог како би произвела што поузданију слику и што тачније приближила видове саодноса између повезаних језичких појава. Метафора је, дакле, наставни ресурс, оруђе конструкције, али и деконструкције, а током усвајања знања представља значајну комуникативну димензију на коју се ослања разумевање градива. Успешне аналогије и метафоре отварају пут бржем и бољем схватању, па тако - будући да добри резултати увек подстичу на нове напоре - постају основ мотивације за рад.

4. Тестови у настави творбе речи (као индикатор слабих места и извор корективних поступака у настави). Тестови утичу на наставу једнако као што настава утиче на тест. Овај писмени облик испитивања не би требало користити само као „мерни инструмент”, већ показатеље успеха обраде, похрањене у одговорима, треба примењивати ради усавршавања методичких приступа. За разлику од испитних тестова у високошколским установама, тестови у основној и средњој школи могу постати драгоцен извор података који се добијају путем утврђивања валидности одговора.

Ваљаност / валидност одговара односи се на утврђивање мере развијености, ефикасности и примерености техника испитивања кандидата у вези с начином (начинима) решавања теста (уп. Алдерсон и др. $\left.{ }^{2} 1996: 294\right)$. Испитивање овог вида ваљаности подразумева разговор наставника са ученицима о процесу одлучивања, размишљања и ангажовању знања, али о видовима ангажовања умећа у решавању тестова током давања одговора на задатке тес- 
та (о умећу решавања тестова исп. Вељковић Станковић 2007б: 211-212). Будући да је немогуће пратити когнитивне процесе ученика током самог тестирања 4 , овај облик „тестирања теста” од стране самих испитаника пружа наставнику драгоцене податке о квалитету, степену и применљивости знања ученика, а такође и о ваљаној конструкцији задатака, формулацији захтева, успешности дистрактора и др.

Анализе и запажања која дајемо уз посебне задатке, одабране као мање или више репрезентативне форме провере знања из области творбе речи, имаће смисла само ако се, уз напор уложен ради установљавања валидности одговора, а у светлу овде наведених тумачења резултата које су испитаници показали, примене у сврху побољшања наставних модела. Тежина задатака може се варирати изменом примера, преформулацијом захтева задатака, бројем и избором дистрактора, те тако наведене анализе у фокусу интересовања задржавају битна методичка питања усвајања знања из творбе речи која се тичу свих нивоа наставе српског језика.

А. Корен и творбена основа.

- Задатак бр. 1

Заокружите слово испред речи у којима су творбене основе обеју речи правилно подвучене:

a) огледалце, родитељски

б) трамвајџија, туђинка

в) младост, чврсто

г) уписни, подзидак

Pешене: в)

Анализа резултата. Од укупно 65 одговора, 42 су тачна (64,6\%), а 23 $(35,4 \%)$ нетачна, при чему дупло више има оних који су се, дајући погрешан одговор, определили за последњи од понуђених парова (г) (укупно 16), док је у 7 случајева изабран дистрактор (б). Занимљиво је да се нико од испитаника није определио за одговор (а), па нас ова околност наводи на два могућа закључка: или дистрактор није био довољно ефикасан, па је било лако уочити грешку (нпр. код родитељски, м. родитељски), или је, макар једним делом, овакав избор условило предубеђење да је први од наведених одговора најчешће нетачан. ${ }^{5}$ Тачан одговор (под в) није било тешко идентификовати, јер су у питању деривати изведени изразито плодним суфиксима, а обе речи су апстрактне именице. Ипак, јасно је да је већина грешака проистекла из нераз-

\footnotetext{
${ }^{4}$ Испитивање валидности одговора продуктивно је непосредније повезивати с наставом, јер се тако већ на самом часу на коме је тест рађен - разуме се, уколико је за решавање потребно мање од 45 минута - могу добити подаци драгоцени и за наставу и за састављање тестова.

${ }^{5}$ Прво. Можда би, аналогно (погрешним) изборима дистрактора г), било боље определити се за друкчију опцију понуђеног одговора, нпр. роди те љ с и. Друго. На елиминацију првог понуђеног одговора, чак и када је он тачан, испитанике може навести мање или више развијено умеће у решавању тестова засновано на искуству, јер није необично да тестатори заиста избегавају да ову позицију изаберу доделе правилном одговору када су у питању задаци вишеструког избора, због чега проминентан положај постаје најмање „видљив”, па му се приликом решавања задатка посвећује мање пажње неголи осталим потенцијалним решењима.
} 
ликовања корена и творбене основе речи, због чега је већина лоших решења усмерена према дистрактору г), у коме су подвучене коренске морфеме. Тако би овај одговор био тачан у случају да се захтев тицао идентификације корена, али не и творбене основе, јер је прид. уписни мотивисан именицом упис (>уписати), док је позидак добијен префиксално-суфиксалном творбом.

Методичка запажањ $a$. Неразликовање творбене основе од корена највероватније је индуковано доминацијом примера првостепених деривата (простих речи) приликом обраде ове наставне јединице, јер се у тим случајевима корен и творбена основа подударају (уп. глават, главоња, главурда; брадица, брадат, брадоња и сл.). Уколико се знање о простој речи (са синхроног становишта), прелазећи на суфиксацију, као на један од доминантаних начина творбе у српском језику, не повеже ваљано с објашњењем једнореференцијалности првостепених деривата, а потом не укаже довољно јасно на творбену и семантичку везу каква се остварује у другостепеним дериватима, пажња ће се најчешће враћати лексичкој / коренској морфеми, и то у складу с потребом да се идентификује семантички стожер творенице. Дакле, недостатак довољног броја квалитетних примера на којима треба показати правце реализације творбеног процеса (нпр. прст - прстен - прстенчић; учити - учитељ - учитељица и сл.), тј. препознати творбене кораке који су довели до формирања одређене творенице води, по правилу, до непоузданих знања о творбеној основи, а самим тим и до неспособности да се идентификује мотивна реч, па и значењска повезаност мотивне и мотивисане речи. Зато творбени процес увек треба што тешње повезивати са значењима, а семантичке саодносе показивати и у примерима током обраде, али и током систематизације и провере знања. Наставни поступци у којима се о наведеним проблемима водило рачуна већ су представљани у методичкој литератури (исп. Штасни 2008: 196), али није наодмет подсетити да овакав начин презентације и утврђивања треба да обухвати и творбену анализу сложеница, јер се и у тим случајевима, аналогно тенденцији каква је показана приликом решавања наведеног задатка, може јавити не само неразликовање сложенице и изведенице, већ и неразумевање значења речи (исто, 251), особито када је укорењена навика механичког издвајања лексичких и/или творбених морфема, а потом и произвољног тумачења њиховог семантичког саодноса.

Усредсређеност на коренску морфему запажа се и у следећем задатку (бр. 2), што показује да је приликом обраде, а посебно током утврђивања знања неопходно посветити више пажње овом проблему.

- Задатак бр. 2

a) Наведите реч која је мотивисала именицу ЗАШТИТА (мотивну реч):

б) Подвуците корен речи ПРЕ Л И С ТА ВАТ И

Решења: а) заштитити; б) ПРЕ ЛИС ТА ВАТ И

Анализа резултата. На оба захтева овог задатка, од укупно 33 студената, тачно је одговорило 11 (33,33\%) (решења: а) заштитити, б) -лист-), док cy $22(66,67 \%)$ испитаника дала исправан одговор само на једно питање, и то 
већином на оно које се тиче корена речи - укупно 20 (60,6\%). Од оних који су дали половичне одговоре, само двоје је погрешно означило мотивну реч и корен: *заш-, *прелист-. Готово сви који су правилно идентификовали корен у другом делу задатка, у првом су делу као мотивну реч навели * $и т и т .{ }^{6}$

Методичка запажања. Једнообразност грешке показује да се твореница посматра само као морфемски и/или гласовни „склоп”, а не доводи се у везу са значењем, у овом случају им. заштита са гл. заштитити, префиксалом гл. штитити. Велик број добро уочених корена речи (у задатку под б) потврђује нашу претпоставку да је знатно лакше тачно одредити коренску морфему но мотивну реч, особито када су у питању добро познате и фреквентне лексеме. Таква идентификација представља неку врсту потраге за „носиоцем смисла”, „најмањом честицом значења” и сл., коју изворни говорници прилично лако запазе према гласовном саставу (мада то може бити и погрешно, уп. вода - воден, водни : водити - водник), или је идентификују методом елиминације свих других делова речи. Зато се, у недостатку знања из творбе, већина изворних говорника служи неким од облика метода „максималне редукције”. Тако, када се у једној речи „препозна” друга (уп. мотивна реч), особито ако је опажена реч кратка, и доведе макар у површну везу са твореницом, биће највероватније означена као корен. Недостатак познавања творбених процеса, или слаб језички осећај, који у овој процени има пресудну улогу, води редукцији на неколико гласова чак и онда када тај гласовни склоп - сасвим очигледно - не може бити носилац лексичког значења (нпр. *заш-).

Иако се у тестовима из матерњег језика знање о творби речи често проверава на изолованим примерима, тј. на деконтекстуализованим речима (твореницама), сматрамо да је много смисленије најпре навести реченицу у којој су изабране речи употребљене, а потом формулисати питање или захтев задатка. Такав је поступак обликовања задатка примењен у следећем случају, али су, за потребе утврђивања и провере знања, могућа различита варирања сличних радних и испитних контекста.

\footnotetext{
${ }^{6} \mathrm{O}$ критеријуму одређивања творбеног правца код речи које се могу сматрати деноминалима, али и поствербалима, нпр. брод - бродити, брус - брусити и сл., исп. Бабић 1986: 285-286. Ради лакше идентификације творбеног смера, Бабић даје једноставан савет: „U određivanju tvorbenog smjera u lingvističkoj je literaturi postavljeno i načelo: ako od dviju riječi koje su u tvorbenoj vezi jedna ima značenje karakteristično za kategoriju kojoj pripada druga, onda je izvedenica prva... Tako su npr. u tvorbenoj vezi riječi bruj i brujati. Imenica bruj ima značenje karakteristično za glagole, označuje radnju 'brujanje', te je prema tome imenica bruj izvedena od glagola brujati' (исто, 286). То се може објаснити и на следећи начин: када именица не значи глаголску радњу, а према себи има глагол, смер мотивације је именица $\rightarrow$ глагол (туга $\rightarrow$ туговати). Уколико именица значи глаголску радњу, обично њен резултат, смер мотивације је: глагол $\rightarrow$ именица (заборавити $\rightarrow$ заборавØ, додирнути $\rightarrow$ додирØ, летети $\rightarrow$ летØ, говорити $\rightarrow$ говорØ и сл. Стога није тешко запазити да им. шттит не значи гл. радњу, те да је од ње изведен гл. ититити, који је мотивисао префиксал заштитити, као мотивну реч им. заштита (изведену од гл. суфиксом -a).
} 
- Задатак бр. 3

Напишите речи које су мотивисале подвучене именице у следећој реченици: Па зар је том дерану, том смутљивцу, првина да изокреће туђе речи!

(a) смутљивац (б) првина -

Решена: (а) смутљив; б) први

Анализа резултата. Од укупно 54 испитаника, 14 их је тачно решило читав задатак $(\mathrm{a}+\sigma) ; 37$ је тачно одредило мотивну реч им. првина (редни број: први), док се већина грешака у првом питању испољила у навођењу гл. смутити као мотивне речи (25), остали одговори били су: мутан 5, мутити 3 , смутьа 2, смутан 1, мутљив 1 , а само три испитаника дала су погрешне одговоре на оба питања.

Методичка запажања. Овакав начин решавања открива да су препознате значењске и творбене везе између гл. смутити и им. смутљиваи; поједини испитаници били су на добром трагу (смутан), вероватно вођени аналогијама (уп. мутан, мутити), али нису препознали прид. смутљив, јер га, сва је прилика, не употребљавају. С друге стране, гласовни склоп речи првина недвосмислено је упућивао на мотивну реч, што је обезбедило добар исход у решавању другог дела задатка. Ипак, не треба изгубити из вида да чак ни на овако једноставан захтев није правилно одговорило $37 \%$ испитаника (20), па се највероватније зато наставници опредељују за још лакше примере, или пак за оне који су много пута поновљени, чиме спуштају праг знања не само лошијим, већ и добрим ученицима, који би били у стању да решавају знатно теже проблемске задатке.

Б. Повезивање семантике и творбе речи у тестовима.

- Задатак бр. 4

Од глагола РАЗМЕТАТИ СЕ и СНЕБИВАТИ СЕ изведите придеве (грађене истим суфиксом) са значењем људске особине:

РАЗМЕТАТИ СЕ > СНЕБИВАТИ СЕ >

Решеље: разметљив, снебивљив

Анализа резултата. Од укупно 64 испитаника, 23 (35,9\%) је дало тачан одговор (снебивљив), остали одговори били су: *снебљив (21), *снебивен (6), *снебивач (2), *снебиван (3), *снадбљив (1), *снобљив (1), *снабежљив (1), *снебиветен (1), *снебојажљив (1), *снабдљивац (1), *снебиватељ (1), * снебивалац (1), * снебиваност (1).

Одговори с ниском фреквенцијом (1-3), њихова разноврсност и обличке девијације показују да гл. снебивати се испитаницима није близак. Извесно је да ова реч не припада ужем вокабулару и да је њено значење непознато, због чега није успешно примењен творбени образац који је доста успешно искоришћен у аналогном одговору на захтев да се од гл. разметати се изведе придев са значењем људске особине. Мада је у захтеву задатка наглашено да треба употребити исти суфикс, што значи да је већ и сама формулација 
могла бити корисна приликом давања тачног одговора, очито је да аномалне творбене основе (уп. ${ }^{*}$ снадбљив, ${ }^{*}$ снобљив, ${ }^{*}$ снабежљьив и сл.) указују на одсуство језичког осећања, а потом и знања о односу мотивне и мотивисане речи. Такође, упркос томе што је казано да се тражи придев, укупно 6 одговора нуди именицу (*снебивач 2 ; *снабдљивац 1 , *снебиватељ 1 , *снебивалац 1 , *снебиваност 1).

Методичка запажања. Занимљиво је уочити да је готово једнак број одговора дат у корист тачног одговора снебивљив (23) и облика *снебљив (21), који бисмо на први поглед могли олако одбацити, баш као и остале погрешне одговоре, али је претрага електронског Корпуса савременог српског језика (КССЈ), а потом и слободна интернет претрага показала да овај облик није неубичајен у свакодневној писменој комуникацији, тј. да није мали број оних који гласовни склоп -ив- у овом придеву доживљавају као неку врсту обличког проширења, па га у деривату изостављају, или су, пак, уверени да се овај придев гради од крње основе. Претпостављамо да се *снебљив овде јавља вероватно по аналогији с придевима грабљив, кажњив, одбрањив и сл., што значи да творбени модел функционише и када је вокабулар сужен, а језички осећај слаб, па се зато понекад могу јавити и потенцијалне речи (исп. Драгићевић 2009), мада су, чини се, у испитним околностима грешке знатно извесније и чешће од потенцијалних речи.

Иако, за разлику од РСЈ, Речник српскохрватског књижевног језика МС бележи гл. снебити се и прил. снебиво, али не и прид. снебив, ни једну ни другу лексему нисмо нашли у електронском Корпусу савременог српског језика, те их не можемо уврстити у узуалне речи. Зато релативно високу фреквентност прид. * снебљив разумевамо као последицу (а) неразвијености лексикона, (б) непознавања творбених образаца матерњег језика, али и као (в) знак да се овакве недостатности из индивидуалних вокабулара лако шире, што показују и примери преузети из дневне штампе и превода књижевних дела познатих стваралаца:

- „Радо бих и ја пустила глас, али плашим се пореметићу песму...”, казала је снебљиво... (КССЈ; Политика, 25. 7. 2011).

- Звезда Оклахоме снебљиво признаје су му играчи... често говорили колико је далеко од неког резултата... (www.nbaserbia.com, 28. 2. 2013).

- Видео је најпре како снебљиво ниче, подрхтавајући на поветарцу... (КССЈ; Луиђи Пирандело, Новеле, Реч и мисао, Београд, 1963).

- „А можда је”, рече Жења снебљиво, „посреди несрећни случај” (КССЈ; Артур Кларк, 2010: Друга одисеја, Београд, Зоран Живковић; превели Мирјана и Зоран Живковић).

- Коначно га је поново зачула. Било је то сићушно, снебљиво крцкање, једва чујно у пригушеном пљускању мора (КССЈ; Тери Прачет, Чудотвораи, Лагуна, Београд 1999).

Други сегмент истог задатка тицао се извођења придева од гл. разметати се и решен је много успешније: 58 тачних одговора (разметљив), а међу нетачнима (укупно 13) нашла су се 3 придева (разметен 5, разметан 2, разметнут 1) и 4 именице (разметливац 2, размеђивач 1, разметалаи 1, разметност 1). Мало је вероватно да су неки од ових одговора резултат читања Гундулићеве религиозне поеме Сузе сина разметнога (још мање познавања библијске параболе, тј. Јеванђеља по Луц̧и), јер би се у том случају подразу- 
мевало и правилно препознавање значења прид. разметан (=расипан; син разметан $=$ блудни син), па и коректан адјективни облик. Верујемо да за успех треба захвалити пре свега високој фреквентности гл. разметати се, као и лексема разметљивост и разметливац у књижевном, али и у колоквијалном језику, што је увелико утицало на лакши и поузданији пут у налажењу тражене речи.

Анализа резултата овог задатка показује да значајан удео у грађењу речи према творбеним обрасцима који постоје у савременом српском језику има развијеност активног вокабулара, те да су већи изгледи да ће се до траженог одговора, тј. творенице доћи уколико се познаје семантика мотивне речи. Пошто се тестови у (основношколској и средњошколској) настави српског језика могу користити и са циљем проширивања речника, овакав облик испитивања потенцијално се показује успешним ако се контекст задатка прошири и у њему употребе бискозначнице. Зато, место побуђивања одговора у нултом контексту, само са (често) недовољним ослонцем на мотивну реч, захтев задатка ваља проширити тако што ће се од ученика тражити да - вођени понуђеном лексемом која ће послужити као творбени ослонац - суфиксално грађеним придевом употпуне наведену реченицу. Текст задатка могао би у том случају гласити „У следећој реченици подвучене речи замени једном, и то придевом изведеним од глагола снебивати се: Када би га друштво наговарало да игра или пева, он је оклевао и у тим ситуацијама био је неодлучан / стидљив / суздржан / плашљив, дакле, (снебивљив)". Чак и ако правилан одговор, као циљ задатка, ни захваљујући таквом олакшању не би био дат, већи број блискозначних придева у садржају захтева допринео би проширивању речника. Сличан тип задатка може се уврстити и у појединачне секвенце приликом састављања и примене материјала програмиране наставе. Тада би ученик који, не одговоривши захтеву, треба да се врати на претходни корак могао да упореди значења наведених лексема и да их, сходно намери спајања наставе језика са развојем културе изражавања, употреби у краћем тексту који треба допунити одговарајућим речима; овакав поступак може се користити и приликом препричавања догађаја, описивања и сл.

Потреба за паралелним испитивањем семантике и одређивањем мотивне речи произилази из непходности разумевања творбено-семантичких односа, али и отварања могућности за коришћење тестова зарад корекције и побољшања методичких модела. Исходи решавања претходног задатка допуштали су нам само претпоставку о познавању значења лексема, што доноси тек делимичну добит када је у питању преобликовање наставних приступа. Зато је следећи задатак осмишљен као симетрична двочлана структура: првим делом проверава се владање семантиком укључених лексема, а други се односи на уочавање полазне речи у творбеном процесу. 
- Задатак бр. 5

Заокруживањем одредите тачна значења наведених придева (А), а потом и речи које су их мотивисале (Б):

1. ХОТИМИЧАН - А. значење: (а) полетан, (б) уходан, (в) пожељан, (г) намеран Б. мотивна реч прид. хотимичан $>$

2. ЛЕТИМИЧАН - А. значење: (а) подесан, (б) површан, (в) неуредан, (г) пролетњи

Б. мотивна реч прид. летимичан $>$

Pешеюе: 1. А. (г), Б. хотимице; 2. А. (б), Б. летимице

Анализа резултата. Очекивали бисмо да корелација између одговора̂ на први и други део задатка буде виша. Резултати су, међутим, у многим компонентама били изненађујући: показало се да испитаници не владају значењима ових адјектива, а да посебних проблема имају са прид. хотомичан и прил. хотимице. Необично је и то што су као мотивне речи навођене не-речи (уп. *хот, *хоти, *хотимик; *летимик, *летимим и сл.), мада је добро познато да изворни говорници брже препознају не-реч од потенцијалне речи (Спирада 2008: 183). Неке од погрешно наведених мотивних речи нису се ни гласовно ни значењски подударале са мотивисаном речју (уп. *тим, *ход, *жеља; *лето, *лак, *уред). Од укупно 61 испитаника задатак је у целости решило само 5 студената $(8,2 \%)$, а значења обеју наведених речи ваљано су одређена само у 9 случајева, што показује да незавидан степен препознавања семантике често прати једнако (не)развијено познавање творбеног обрасца. Поред тога, број оних који нису дали никакав одговор сматрамо необично високим, особито када се има у виду да се радило о задатку вишеструког избора, тј. да су одговори - а међу њима и онај који је тачан - били понуђени.

Прегледну дистрибуцију, фреквентност и разноликост добијених решења (тачних и нетачних) представљамо у следећој табели:

\begin{tabular}{|c|c|c|}
\hline \multicolumn{3}{|c|}{ Решења задатка бр. 2} \\
\hline испитаника ук. 61 & А. значење & Б. мотивна реч \\
\hline 1. ХОТИМИЧАН & $\begin{array}{l}\text { (а) полетан } 13 \\
\text { (б) уходан } 8 \\
\text { (в) пожељан } 6 \\
\text { (г) намеран } 27 \\
\text { без одговора } 7\end{array}$ & $\begin{array}{l}\text { - тачних одговора ук. } 9 \\
\text { - нетачних одговори ук. } 33 \text { : хтети } 10 \text {, } \\
\text { хотимичност } 3 \text {, хотимично } 3 \text {, хот } 3 \text {, } \\
\text { ход } 2 \text {, хоти } 2 \text {, хотим } 2 \text {, жељан } 2 \text {, хо- } \\
\text { тимик } 1 \text {, жеља } 1 \text {, тим } 1 \text {, хотимим } 1 \text {, } \\
\text { хотимит } 1 \text {, хотити } 1 \\
\text { - без одговора ук. } 19\end{array}$ \\
\hline 2. ЛЕТИМИЧАН & $\begin{array}{l}\text { (а) подесан } 5 \\
\text { (б) површан } 41 \checkmark \\
\text { (в) неуредан } 3 \\
\text { (г) пролетњи } 4 \\
\text { без одговора } 8\end{array}$ & $\begin{array}{l}\text { - тачних одговора ук. } 9 \\
\text { - нетачних одговори ук. } 34 \text { : лет } 8 \text {, ле- } \\
\text { тети } 6 \text {, летимично } 4 \text {, летимичност } 3 \text {, } \\
\text { лето } 3 \text {, лети } 2 \text {, летим } 2 \text {, летњи } 1 \text {, ле- } \\
\text { тимик } 1 \text {, летимим } 1 \text {, летимит } 1 \text {, лак } 1 \text {, } \\
\text { уред } 1 \\
\text { - без одговора ук. } 18\end{array}$ \\
\hline
\end{tabular}


Наведена решења откривају следеће: када се реч не познаје, и када се не може изазвати и/или наћи контекст подесан за препознавање, испитаник прибегава анализи гласовног склопа и поређењу с познатим речима и облицима. Такође, немогућност одређивања творбене основе или, у конкретном случају, мотивне речи (што се види по великом броју изосталих одговора) последица је семантичке недостатности која се покушава превазићи свесном продукцијом аномалних облика (*летимик, *летимит и сл.), мада је сигурно да их испитаници никада нису ни чули нити употребили. Ипак, они који су разматрали понуђене одговоре и упоређивали их с гласовним склопом познатих речи, или чак с онима које су део периферије пасивног вокабулара, наслутили су порекло лексеме (летимице - летети; хотимице - хтети). ${ }^{7}$

Методичка запажања. Поређењем првог и другог сегмента одговора̂ везаних за обе творенице запажамо да су неки дистрактори утицали на одређивање мотивне речи, која је тада, разуме се, гласовно одступала од творенице за коју је питање било везано, али је била семантички усаглашавана с претходно датим погрешним одговором: уп. одговоре 1. А. (в) пожељан : Б. жељан, жеља; 2. А. (г) пролетњи : Б. лето, летњи.

Код оваквих задатака разложно је применити проверу валидности одговора (уп. Вељковић Станковић 2007б: 213-214), јер је такво методичко поступање веома корисно не само за оне ученике који нису савладали елементарна знања о творбеној основи, већ и за боље ученике, који могу добити додатну информацију из области историје језика и етимологије. Тако би чак и оне који су грешили вероватно обрадовало сазнање да П. Скок за прилог хотимице каже да је настао од поимениченог старог партиципа презента пасива hotim: „Od hotim stvoren je prilog na -icē: hotimice, nehoti(mi)ce, odatle opet pridjev na -ьn (ne)hotimičan” (Скок 1971, s.v. hòtjeti); овај аутор такође помиње поствербале hot $\mathrm{m}$, f, hota f (18. в.), и додаје „Posljednji je živ i danas u prefiksalnoj složenici pohota $\mathrm{f}=$ bug. pohot”. Прилог летимице П. Скок помиње у вези са прилошким суфиксом -це, који служи за „,raširivanje priloga nastalih parasintaktičkim putem” (нпр. узастопце, постранце, непрестанце): „Rašireniji je -ice, naročito u vezi s priloškim -om: kradom > kradomice, kriomice, danomice uz danimice, letimice (odatle pridjev letimičan)"; уз то, Скок показује везу с гл. летјети: 'Prilozi na -imice letimice (18. v., Srbija), odatle pridjev na -ьn letimičan (pogled)' (исто, s.v. letjeti)" (исп. Скок 1971).

То је уједно и добра прилика да се прошире знања из семантике и упознају облици и значења других прилога добијених истим творбеним моделом (крадомице, даномице). Наиме, испитивање начина на који су одговори током тестирања давани доноси значајне информације о квалитету знања, степену његове усвојености, али и о недостацима наставе, којима треба посветити додатну пажњу након анализе постигнућа на тесту. Имајући у виду овде

${ }^{7}$ Мотивација се у савременој дериватологији посматра као „формално-семантичка веза између двеју речи" (Ћорић 2008: 23, 25), али, када таква веза није довољно прозирна, добро је укључити и етимолошки аспект (Штасни 2010: 89), што је прилика да се у наставу (с мером) уведу и етимолошки речници и тиме оснажи заинтересованост ученика за тражењем порекла лексема. 
показане резултате, испитивање валидности одговора у наведеном задатку требало би да буде усмерено најпре на семантику, а тек потом на творбу.

Сличне резултате, па и закључке доноси анализа постигнућа у решавању задатка у коме је именице требало извести од придева:

- Задатак бр. 6

Од придева ПОДАО, ГРУБ и ЛАКОМ изведите именице којима се именују носиоци ових негативних особина (нпр. прост > простак; опасан > опасник и сл.) и напишите их у облику номинатива једнине мушког рода:

а) подао - _ б) груб , лаком -

Pешеъа: а) подлац (подлак), б) грубијан, в) лакомац (лакомник)

\begin{tabular}{|c|c|c|c|c|c|c|}
\hline \multicolumn{7}{|c|}{ Резултати (укупно 65 испитаника) } \\
\hline & $\begin{array}{c}\text { тачни } \\
\text { одг. }\end{array}$ & $\%$ & нетачни одговори & $\%$ & $\begin{array}{c}\text { без } \\
\text { одговора }\end{array}$ & $\%$ \\
\hline a) подао & 48 & 73,8 & $\begin{array}{l}12 \\
\text { поданик } 4 \text {, подан } 2 \text {, под- } \\
\text { лик } 1 \text {, подник } 1 \text {, подаок } 1 \text {, } \\
\text { падавичар } 1 \text {, под } 1 \text {, под- } \\
\text { лост } 1 \text {, }\end{array}$ & 18,5 & 5 & 7,7 \\
\hline б) груб & 50 & 76,9 & $\begin{array}{l}9 \\
\text { грубник 5, грубак 2, } \\
\text { грубљан 1, грубост } 1\end{array}$ & 13,9 & 6 & 9,2 \\
\hline в) лаком & 18 & 27,7 & $\begin{array}{l}34 \\
\text { лакомислен } 7, \text { лакоман } 5 \text {, } \\
\text { лакомисленик } 4 \text {, лаком } 2 \text {, } \\
\text { лак } 2 \text {, лаки } 1 \text {, лако } 1 \text {, ла- } \\
\text { коми } 1 \text {, лакан } 1 \text {, лакомик } \\
1 \text {, лакомак } 1 \text {, лакомичар } \\
1 \text {, лакомислилац } 1 \text {, лако- } \\
\text { мислац } 1 \text {, лакомијан } 1 \text {, } \\
\text { лаковеран } 1 \text {, лакомџија } 1 \text {, } \\
\text { лакомњак } 1 \text {, лакомисле- } \\
\text { ност } 1\end{array}$ & 52,3 & 13 & 20 \\
\hline
\end{tabular}

Методичка запажања. Када је мотивна реч задата (а тражи се твореница), као што је то случај у овом и задатку бр. 4, изгледи да ће се добити тачан одговор управно су пропорционални фреквентности мотивне речи у идиолекту испитаника. Управо из тих разлога на часовима обраде препоручљиво је избегавати непознату или мање познату лексику. Ипак, у вежбе и систематизију градива пожељно је укључивати речи које би ученици требало да усвоје, па и оне које су мање фреквентне; тада треба наводити значења а циљне речи употребљавати контексту у коме би њихова семантика могла бити препозната. Овакво поступање односи се не само на наставни приступ 
творби речи, већ и другим областима језика (фонетици, морфологији, синтакси). Такође, не треба подлећи заблуди да се вокабулар ученика шири само на часовима посвећеним књижевности, док се на часовима језика стиче искључиво лингвистичка компетенција, јер се обе предметне области складно допуњују с културом изражавања и само у околностима њиховог добро одмереног повезивања и прожимања можемо очекивати остварење наставних циљева предмета Српски језик и књижевност.

Као и код претходних задатака, очито је да непознавање семантике кореспондира с немогућношћу остварења творбеног акта: када је лексема позната, у решењима се налази мање не-речи и обрнуто. Разгледајући задатке 3-6, закључујемо да су лексеме смутљиваи, смутљив, снебивати се, снебивљив, хотимичан, хотимице, лаком и лакомач мање познате од осталих које су укључене у захтеве теста, а исто можемо претпоставити за друге деривате ових основа. Истовремено, управо за њих везан је велик број неречи, а највећу продуктивност запазили смо код извођења именице (nomina attributiva) од прид. лаком. Због настојања да се значење одгонетне, испитаници често не обраћају пажњу на врсту тражене речи, па се овде јавио знатан број придева који су навођени место траженог деадјективног супстантива (лак, лакомислен, лаковеран, *лакан и др.). У многим случајевима видимо да се не-речи и други погрешни одговори продукују према начелу „препознавања" или асоцијације. Тако се фокална реч задатка повезује с каквом фреквентнијом, испитаницима познатом лексемом чији се почетни гласови подударају с гласовним склопом мотивне речи; овакав процес запажамо не само код прид. лаком, већ и подао (под, поданик, *подаок, *подлик) и груб (*грубак, *грубљан). Занимљиво је и то да је творбена инвентивност, мада се кретала у погрешном смеру, највећа код непознатих речи (*лакомичар, *лакомислилац, *лакомислац, *лакомијан; *хот, *хоти, *хотим и сл.), при чему се издвајају два манира: насумичан покушај и посезање за првом познатом узуалном речју, тј. асоцираном основом. Такав тип одговора може се унеколико оправдати притиском који ствара испитна ситуација. Ипак, пошто је у неким случајевима самим текстом захтева олакшано решавање (уп. задаци бр. 4 и 6), можемо закључити да су нетачни одговори пре индикатори непознавања значења мотивне речи, па самим тим и (траженог) деривата, или знак слабе употребе задатком подстицаних творбених модела, што је по вокабулар појединца штетније.

5. О перцепцији непознатих речи. Видели смо да чак и анализа задатака из области творбе речи може постати добар индикатор развијености активног лексикона, а испитивање валидности одговора, разуме се, доноси много боље резултате у погледу установљавања основних недостатака наставе и усвајања знања. Основни проблем, дакле, није увек непознавање механизама творбе, већ и лексичка недостатност која отежава творбени акт. Други важан проблем јесте што непознате речи све чешће припадају кругу оних које би испитаницима одређеног узраста и степена образованости требало да буду познате. Трећи се, пак, односи на изједначавање непознатих речи са страним речима. Потоњи закључак долази након анкете спроведене школске 
2015/16. године на ограниченим узорку (65 студената 3. године групе 01). Циљ је био да се открију лексичке недоумице испитаника и њима блиских саговорника. Анкета је била једноставна, имала је само два захтева: 1. „мени непознате речи" (да испитаници наведу речи које су чули али им значења не познају, или им нису сасвим јасна), 2. „другима непознате речи” (да напишу оне речи које њихови саговорници нису разумели, у вези с којима су исказали недоумицу или које су употребљавали с неодговарајући значењима). Резултати анкете показали су да је највећи број непознаница међу именицама (191), далеко мањи међу придевима (34) и глаголима (23), а најмањи када су у питању прилози (14). Ово је, рекли бисмо, само један делић комплексне слике лексичких потенцијала младих и образованих говорника. У складу с тим, на резултатима ове анкете не могу се градити генерализације, али их можемо сматрати једним од показатеља начина поимања непознатих речи и усмерености лексичких недоумица.

Запазили смо да је пажња испитаника понајпре била окренута речима страног порекла, као и лексици која се обично јавља у академском контексту: фуснота, контрадикторност, опсерваиија, дигресија, метафизика, дис$к у р с$, инхибииија и др. С обзиром на професионално опредељење студената, сасвим је очекивано што је међу лексемама које су издвојене као „другима непознате" било и више термина из области за које су заинтересовани (прозодија, калк, интертекстуалност и сл.).

Поред лексема које означавају родбинске односе (јетрва, заова, свастика, патеног), међу речи које су запазили да њихови саговорници користе с погрешним значењима или их, пак, у разговору употребљене не разумеју, испитаници су убројали и ове: баријера, бехар, бостан, војна, дактилограф, драгстор, Ђувегија, задруга, касаба, кладенаи, креденац, мангуп, поњава, разбој, расковник, сои, тағирача и сл. Ако за неке од њих претпоставимо да су мање фреквентне и/или неким говорницима српског језика донекле стране због непознавања референта (креденаи, разбој, тањирача, поњава, расковник и сл.), промене социјалних односа (задруга, менза), напретка технологије, а с тим у вези и нестанка неких занимања (дактилограф), ипак остаје довољан број оних лексема за које бисмо, без обзира на њихово порекло, с правом могли очекивати да припадају заједничком лексикону (мангуn, Ђувегија, чланак (=текст), кладенац, ведро, бостан, касаба и сл.). Мада је застаревање речи уобичајено и очекивано, овакви резултати показују да се активан речник младих сужава, па тако све већи број реалија и појава говорницима постаје не само језички, већ и појмовно непрепознатљив, што значи да замашни сегменти искуства и знања тону у заборав, а њихов недостатак у изразном реквизитаријуму обично не бива допуњен новом лексиком.

Ваља истаћи још једну чињеницу, важну за наставу морфологије: непознавање речи корелира са употребом аномалних облика, па је тако добар број лексема које су окарактерисане као недовољно познате (самим испитаницима) неправилно написан: *коресподенција м. кореспонденција, *реминесценција м. реминисценција, *хермеутика м. херменеутика, *контеплација м. контемплација. 
Неки додатни коментари, навођени уз покоју реч, потврдили су да је презентација речи у вокабулару повезана с ванлингвистичким знањима (посебно ако је у питању конкретнопредметни ентитет): шненокле („Знам да је врста колача, али их нисам видела до сада.”), проја („Моја бака из Црне Горе тако зове хлеб од кукурузног брашна.”), орнамент („Које је основно значење?").

Овоме ћемо додати и запажање да студенте Катедре за српски језик и јужнословенске језике на мастер студијама интересују теме које се тичу употребе речника у настави, а такође и оне које се односе на развој културе изражавања, језик и стил писаца, лексику у домаћим филмовима, лексику традиционалне српске културе и сл. Сачињавајући и проучавајући језичке корпусе, као основе за писање својих семинарских и мастер радова из области Методика наставе српског језика, будући наставници матерњег језика стичу компетенције које ће применити у школама и то охрабрује, јер ће у свом професионалном раду свакако бити окупирани жељом и потребом да побољшају интегративне методичке приступе у настави српског језика.

6. Закључци и методичке препоруке. Навођење лексикографских дефиниција и упућивање на тумачења ученицима непознатих речи, каква се обично дају у уџбеницима, на наставним листовима или усмено, током часа, нису увек довољно ефикасни поступци у проширивању речника и побољшању усменог и писменог изражавања. Истинско усвајање нове лексике обезбеђују тек развијене читалачке навике, дужа употреба лексема у различитим контекстима и континуитет прожимања наставних садржаја из свих области предмета Српски језик и књижевност. Ове чињенице су, истина, одавно познате, али је у настави тешко удовољити им јер опширни програми не дозвољавају веће задржавање на истим садржајима. Таква ситуација обавезује нас да налазимо ефективније вежбе и разнолике, а дугорочно применљиве стратегије проширивања вокабулара.

На часовима посвећеним утврђивању и систематизацији знања из творбе речи обично се дају примери веома фреквентних лексема чија значења ученици добро познају; тако се наводно штеди време, али штета је вишеструка: знања о грађењу речи не напредују много јер се код познатих речи најчешће довољно добро разазнаје и творбени састав. Поред тога, творбени образац се не шири на друге лексеме, нити се детаљније показује утицај истог творбеног елемента у споју с другим основама, тј. речима; самим тим се фокус учења сужава, а творбени обрасци остају тек дотакнути, као неотворени поклони који се незахвално одбацују.

Постоји неколико начина да се творба речи формално обради, али без много доприноса применљивости граматичког знања, још мање богаћењу речника. Истовремено, безброј је добрих методичких модела којима се ова, делом већ постојећа знања могу активирати и тако допринети не само јачању индивидуалних изражајних моћи, већ и интересовању за лексичко благо нашег језика.

Неопходно је идентификовати основне препреке у стицању теоријског знања и отклонити терминолошке и појмовне недоумице (нпр. неразлико- 
вање корена и творбене основе, творбене и граматичке основе), у чему велики удео може имати укључивање продуктивних метафора у наставни дијалог. На пример, метафора генеалошког стабла (/пра/родитеља), коју је применио А. Белић, може имати добар објашњавачки потенцијал у оспособљавању ученика да идентификују мотивацију првостепених, другостепених и трећестепених деривата. Старијим ученицима овај однос може постати јаснији применом метафоре кретања, тј. творбених корака (учити $\rightarrow$ учитељ $\rightarrow$ учитељица $\rightarrow$ учитељичин; учитељ $\rightarrow$ учитељски и сл.), помоћу којих се, идући напред, али и враћајући се, лакше препознају мотивне речи. У свим узрастима треба избећи разумевање творбених начина као машина или механиз(а)ма. Мада се о „механизмима творбе” често говори и пише, они нису срећан извор метафора у настави, јер се преко њих не могу објаснити нпр. крње основе (пошто машина увек даје истоветне, правилне продукте), па ни многе друге језичке појаве (перинтеграција, језичка економија и др.). Зато, место метафоре фабрике речи, боље је користити метафору креативних модела (уп. творбени модел). Млађе ученике добро је подсетити како су у детињству, управо захваљајући њима, „стварали” нове речи, тј. трагали за поузданим „одливком” за оно што су хтели да именују. Тако, током усвајања матерњег језика, настају многе дечје „речоломке”: *улепотати (се) : лепота, м. улепшати (се), *уместити (се) : место, м. сместити (се); прослаткити се : сладак, м. постати сладак; *услаткити м. засладити и др.). Тако се показују стална жеља и непоходност да се зарад споразумевања творе нове речи чак и онда када се творбени обрасци тек наслућују и упознају.

Ова потреба, па и фасцинација речима и именовањем може се показати на богатом лексичком материјалу великих описаних речника, на примерима неологизама (РСЈ: домисао, укрупьавати /се/, документарац и сл.), поетизама (жаран, жарковит, крилоног, лакокрил, медоуст, неболоман и сл.), па и жаргонизама (гребатор, губиташ, гуранција и др.). Дела многих значајних писаца и песника треба да постану не само предмет тумачења, већ и језичке анализе, а ученике ваља упознати и с интересовањима знаменитих стваралалаца за бележење речи чутих у народу (уп. Андрић 1997: 42: За човека у Босанској крајини: свесебица = себичњак, саможивац; памтииа = причало, песник; незаглављен = врлетан; мртваја = куњало; Костић 2007: кваренда = човек који квари друштво у Бачк.; летораст = гранчица израсла оног лета; одљуд = који бежи од људи и сл.). Повезивање с наставом књижевности најбоље је реализовати кроз портретисање, карактеризацију, дескрипцију (ентеријера и екстеријера), описивање вербалног и невербалног понашања јунака, исказивање ставова приповедача, усклађивање лексике са тематиком, саговорником, ситуацијом и др. Уз то, као материјал за стилске и језичке вежбе добро је давати одломке из писмених задатака, јер се часови исправке обично недовољно искористе за рад на богаћењу језика.

Типске лексичке и семантичке вежбе обично су базиране на подстицању ученика да на основу једне наведене речи дају њен антоним, синоним, а када је реч о творби, да изведу - како се то обично каже - што више деривата од понуђене мотивне речи и сл. Овакво лексичко побуђивање само је донекле 
ефикасно, јер се њиме заправо пре проверава опсег учениковог речника но што се он богати. Најпре зато што се не може изазвати реч која већ не постоји у активном лексикону, а потом и стога што вежбе које се одвијају у нултом контексту не одговарају природном усвајању лексике, па ни учењу граматике (уп. комуникативно-функционални приступ).

Лексичку недовољност треба запажати и у усменом и у писменом изражавању, па тако стварати „банке” непознатих речи, које се могу користити за осмишљање „загонетних прича” о речима. Садржај сваке приче треба да открије природу, изглед, начин употребе одређеног предмета, или да оцрта понашање, нарав и навике особе која је окарактерисана циљном речју и сл. Ученици се могу и сами окушати у именовању и грађењу нових речи (уп. потенцијалне речи), али је, пре тога, важно упознавати их с потенцијалом продуктивнијих творбених модела.

Најзад, у систематизацију, као и у проверу знања писменим путем, тј. у тестове наставника треба уврстити речи високе, али и знатно ниже фреквенције, а захтеве задатака усмерених на примену знања из творбе речи што чешће повезивати са семантиком ради запажања промене значења у творбеном акту, при чему примерима ваља обезбедити место у природном и достатном контексту.

\section{ИЗВОРИ}

Андрић 1997: Иво Андрић, Свеске, Београд: Просвета.

Костић 2007: Лаза Костић, Допуна Вуковог Рјечника, Београд: Чигоја штампа.

КССЈ: Корпус савременог српског језика Математичког факултета Универзитета у Београду <http://www.korpus.matf.bg.ac.rs/korpus $>10.5 .2016$.

PMC: Речник српскохрватскога кюижевног језика, I-VI, Нови Сад: Матица српска (1967-1976).

РСАНУ: Речник српскохрватског книжевног и народног језика (т. I-XIX), Београд: САНУ, Институт за српски језик (1959-2014).

PCJ 2007: Речник српскога језика (ур. М. Николић), Нови Сад: Матица српска.

Скок 1972: Petar Skok, Etimologijski rječnik hrvatskoga ili srpskoga jezika (Knj. 2), (uredili Mirko Deanović i Ljudevit Jonke; surađivao u predradnjama i priredio za tisak Valentin Putanec), Zagreb : Jugoslavenska akademija znanosti i umjetnosti.

Интернет извори: www.blog.b92.rs <22. 12. 2016> ; www.webtribune.rs $<10.12 .2016>$

www.nbaserbia.com $<28.2$. 2013> 


\section{ЛИТЕРАТУРА}

Алдерсон и др. ${ }^{21996: ~ C h a r l e s ~ A l d e r s o n, ~ C a r o l i n e ~ C l a p h a m, ~ D i a n n e ~ W a l l, ~ L a n-~}$ guage Test Construction and Evalution, Cambridge: Cambridge University Press.

Белић 1932: Александар Белић, Граматика српскохрватског језика за други разред средњих и стручних школа, Београд: Издавачка књижарница Геце Кона.

Белић 2000: Александар Белић, Граматике. О граматикама. Изабрана дела Александра Белића, т. 12 (приређивач Даринка Гортан-Премк). Београд: Завод за Уџбенике и наставна средства.

Вељковић Станковић 2007а: Драгана Вељковић Станковић, „О терминима у области тестирања знања из матерњег језика", Научни састанак слависта у Вукове дане, 35/3, 187-202.

Вељковић Станковић 2007б: Драгана Вељковић Станковић, „Методички и терминолошки аспекти односа тестирања и наставе српског језика", Научни састанак слависта у Вукове дане, 35/3, 203-219.

Драгићевић 2009: Рајна Драгићевић, „Потенцијалне речи у српском језику”, Научни састанак слависта у Вукове дане, 38/3, 119-126.

Драгићевић 2011: Рајна Драгићевић, „О неким особеностима творбе неологизама у настави", Књижевност и језик, LVIII 1-2, 2011, 89-97.

Лoy 2008: Graham Low, „Metaphor and education”, in: The Cambridge Handbook of Metaphor and Thought (ed. Raymond W. Gibbs, Jr.), Cambridge: Cambridge University Press.

Милановић 2009: Александар Милановић, „Дериватолошка методологија у новијим монографијама о језику писаца предвуковске епохе”, Научни састанак слависта у Вукове дане, 38/3, 127-136.

Николић 42006: Милија Николић, Методика наставе српског језика и књижевности, Београд: Завод за уџбенике и наставна средства.

Петровачки и Штасни 2008: Љиљана Петровачки, Гордана Штасни, Meтодичке апликаиије: планирање, програмирање и припремање наставе српског језика и къижевности, Нови Сад: Филозофски факултет, Одсек за српски језик и лингвистику.

Спирада 2008: Pushpa Nagini Spirada, „Mental Lexicon”, Journal of the Indian Academy of Applied Psychology, 34/1, 181-186.

Xjy3 ${ }^{132001:}$ Arthur Hughes, Tesing for Language Teachers, Cambridge: Cambridge University Press.

Штасни 2008: Гордана Штасни, Творба речи у настави српског језика, Београд: Друштво за српски језик и књижевност Србије.

Штасни 2010: Гордана Штасни, „Мотивациони смерови у деривационим процесима", Зборник Матице српске за филологију и лингвистику, LIII/2, 89-97. 
Dragana D. Veljković Stanković

\section{ON LEXICON DEVELOPMENT IN WORD FORMATION TEACHING}

\section{Summary}

In this paper we deal with improvement of correlative-integrative approach in teaching Serbian as mother tongue. Taking into consideration that students' abilities correlate with weaker and weaker reading habit and applying reproductive-explicative methods in language teaching, the improvement of teaching and knowledge quality are seen in conjoining and interacting within subject domains and in the focus of this consideration are word formation teaching and expressing culture. The goal of integrative and communicative approach is students' ability to apply their knowledge actively on word formation together with their vocabulary enhancement, and basic preconditions for realization of these tasks are as follows (a) more intensive conjoining word formation teaching with semantics; (b) a thorough presentation and better differentiation of basic concepts and terms from this domain (explanatory function of conceptual metaphors in teaching); (c) the use of systematization and written knowledge tests for improving active vocabulary (backwash test effect, response validity).

Key words: word formation, correlation within subject, active vocabulary, conceptual metaphors in teaching, tests, response validity. 